Media Industries $5.2(2018)$

\title{
The Fan/Creator Alliance: Social Media, Audience Mandates, and the Rebalancing of Power in Studio-Showrunner Disputes
}

\author{
Annemarie Navar-Gill ${ }^{1}$ \\ UNIVERSITY OF MICHIGAN \\ amngill [AT] umich.edu
}

\begin{abstract}
Because companies, not writer-producers, are the legally protected "authors" of television shows, when production disputes between series creators and studio/ network suits arise, executives have every right to separate creators from their intellectual property creations. However, legally disempowered series creators can leverage an audience mandate to gain the upper hand in production disputes. Examining two case studies where an audience mandate was involved in overturning a corporate production decision-Rob Thomas's seven-year quest to make a Veronica Mars movie and Dan Harmon's firing from and subsequent rehiring to his position as the showrunner of Community-this article explores how the social media ecosystem around television rebalances power in disputes between creators and the corporate entities that produce and distribute their work.
\end{abstract}

Keywords: Audiences, Authorship, Management, Production, Social Media, Television

Scripted television shows have always had writers. For the most part, however, until the post-network era, those writers were not "authors." As Catherine Fisk and Miranda Banks have shown in their respective historical accounts of the WGA (Writers Guild of America), television writers have a long history of negotiating the terms of what "authorship" meant in the context of their work, but for most of the medium's history, the cultural validation afforded to an "author" eluded them. ${ }^{2}$ This began to change, however, in the 1990s, when the term "showrunner" began to appear in television trade press. "Showrunner" is an unofficial title referring to the executive producer and head writer of a television series, who acts in effect as the show's CEO, overseeing the program's story development and having final authority in essentially all production decisions. Although the job had existed prior to the 
creation of this shorthand term, the emergence of this word became tied to a new discourse of authorship that helped to legitimate television as a creative medium. ${ }^{4}$ Eventually, the figure of the showrunner as author became a signal of quality for television programming. ${ }^{5}$ Eventually, the rise of online television fandom further bolstered this authorship discourse through an increase in entertainment news media coverage focused on showrunners and their creative processes and an increased focus on personal social media engagement on the part of showrunners themselves. ${ }^{6}$

The quasi-celebrity-or in the case of the biggest names, full celebrity-author status afforded to showrunners in contemporary television cultures in some ways obscures the more complex power dynamics that actually go into producing television. Although showrunners have a great deal of creative authority within their own writing and production offices, they still answer to the executives at studios and networks. If there is a serious dispute between a showrunner and these executives, as a contracted employee, the showrunner can simply be dismissed. At this point, they have no rights to continue working with what we would colloquially think of as "their" intellectual property. ${ }^{7}$ This article teases out developments in American scripted television-including contemporary discourses on television authorship and the rise of social media fandom of showrunners - to explore the ways in which audience support can shift the balance of power during situations of conflict between showrunners and studio executives. To explore the options open to television creators who lose control over their creations in this modern cross-platform media ecosystem, I examine cultural discourses surrounding Dan Harmon's firing from and subsequent rehiring to his position as executive producer of Community (2009-2015) and Rob Thomas's seven-year quest to make a Veronica Mars (2004-2007) movie. Based on these case studies, I argue that audience perceptions of authorship can provide series creators the leverage they need to gain the upper hand during disputes with the studio and network. This happens because audience validation of the showrunner as an artistic driving force behind a series makes that showrunner more essential to corporate commercial interests. In this way, fans serve as symbolic patrons for showrunners, helping them gain greater status and commercial viability by buttressing their artistic status.

\section{Theorizing the Showrunner as Author}

Contemporary discourses about showrunners extend a longer history throughout which television writers have sought to strike a balance between artistic respect and their rights as workers. ${ }^{8}$ Legally, writing for the screen is considered "work for hire," which means that the writers' employer is legally considered the author of the work and owns its intellectual property. ${ }^{9}$ Over the course of the union's history, the WGA's collective bargaining agreements have ceded this legal type of authorship while using the crediting process to strategically position screenwriting as the creative work of individuals, intended to create a public perception of screen texts as authored. ${ }^{10}$ While films are more often seen as "authored" by their directors, television has maintained the public image of being a writers' medium. ${ }^{11}$ This perception gives rise to a commonsense understanding of the creator of a series as its visionary and steward, despite the fact that the television studio is the program's author in the eyes of the law. As Catherine Fisk has argued, both social and legal "processes of recognition" 
constitute the relationship between people and intellectual property ${ }^{12}$ yet the situation of "work for hire" creates situations in which social and legal recognition may be at odds with each other.

Because of this tension, the increased visibility of the showrunner's figure in the digital era can be a double-edged sword for the corporate owners of television's intellectual property. A respected showrunner can offer buzz for a series that is more valuable than the corporate brand of a studio or network. The figure of the showrunner provides an artistic legitimation that serves a commercial function by acting as a brand name and guarantor of quality. Thus, television's corporate authors cede their visibility to showrunners and creators to benefit from the ways in which authorship frames audience reception. If a television series creator (or the executives he or she answers to) wishes to exert control over his or her creation, they can lean into their showrunner persona through a variety of ancillary content channels such as trade press, social media interactions, DVD commentary tracks, and podcasts. ${ }^{13}$ Together, these channels shape the audience's image of a particular showrunner as a singular author. They can be used to promote the showrunner's textual authority and push certain reading strategies. In this way, showrunners are often as much authorial paratexts as people, "conditioning our entrance into texts" by both preparing us to evaluate them in a certain way before we engage and shaping our reading strategies once we have. ${ }^{14}$

However, investing the show's value too heavily in the showrunner holds risks as well. ${ }^{15}$ While industry can endorse and push particular perceptions of an authorial brand, the audience must be willing to buy in and actually confer that validation. A change in showrunner-such as Marti Noxon replacing Joss Whedon for season six of Buffy the Vampire Slayer (19962003)-can significantly damage audience perception of a series. ${ }^{16}$ Even if little actually changes in the day-to-day writing and production of a series, the departure of a showrunner who is overdetermined as its author figure potentially creates a public relations issue for studios and network. Showrunners are thus allowed to serve as the public faces of their shows, at least until either the showrunner or the show itself becomes financially problematic.

\section{Audiences and Authorship in Television's Social Media Era}

When a showrunner's authorial paratext is well established, the audience tends to see that television auteur as the true owner of their show. Fans have a vested interest in protecting quality storytelling from economically motivated management that might destroy its artistic integrity. ${ }^{17}$ When they feel something has gone wrong with a beloved series, fans often react by blaming the network, seeing themselves as aligned with the creator and in opposition to any "powers that be" they think may mishandle a beloved story-through cancellation or ill-advised creative input-in an attempt to achieve greater economic profit from the show. ${ }^{18}$ Since the 1960s, fans have often come together against television corporations to protest the cancellation of beloved series with "save our show" campaigns. While the approaches used in such campaigns have evolved significantly from focusing on simply informing networks about their passion for the shows to directly courting advertisers, they are important precursors to the 
fan/creator alliance in that they served as a testing ground for tactics that invested parties without legal rights might use to pressure television production's corporate parties into reconsidering their decisions. ${ }^{19}$ Although production personnel have occasionally participated in or publicized these fan campaigns, they have largely been grassroots efforts.

Where fan/creator alliances I discuss here are distinct from fan campaigns of the past is in the way that they are industrially driven and leverage the relationships enabled by the social media ecosystem that has developed around television. In this ecosystem, social media platforms provide a direct line of communication between audiences and productions. The labor of maintaining these communicative links is now a part of everyday work practice for television producers. ${ }^{20}$ While both the architecture of social media and the industrial practices that have developed around its use make it an effective tool for modeling and channeling fan conversation in ways that are productive for industry, these spaces still afford audiences a certain amount of influence on industry because they have a great deal of control over public-facing conversations that contribute to the brand images of particular networks, studios, programs, and personnel. ${ }^{21}$ Increasingly, savvy showrunners use their social media accounts as spaces for building a personal authorial brand and developing connections with their audiences. Skillfully deployed, such connections can deepen fan interest in the showrunner's work and the notion that it is driven by an authorial vision. In examining the cases of Veronica Mars and Community, I show how an individual showrunner can-building on both the history of fan campaigns and their own personal relationships with the audience-turn to their fans for help when frustrated by a corporate production decision. The success of these attempts is reliant on how well the showrunner has cultivated fan investment in their authorial paratext.

\section{Proof of Audience: The Veronica Mars Kickstarter Campaign}

In its three years on the air, first on the UPN network and then the fledgling CW, Veronica Mars (2004-2007) never left the basement of the Nielsen ratings, placing solidly in the bottom ten shows on network prime time for its entire run. As a result of these ratings, its 2005 and 2006 renewals - on the strength of critical interest and a devoted cult following-were at least something of a surprise, and its cancellation in 2007, though disappointing for the faithful, seemed inevitable. Over the course of the six years that followed, however, it became quite apparent the show's creator, Rob Thomas, was far from finished telling the story of Veronica Mars. But he could not write any more stories about her-in any medium-because Warner Brothers owned the intellectual property associated with the character. Faced with this situation, most television series creators simply move on from the canceled property and continue elsewhere. Although Thomas did too, he used the platforms he received as a result of creating Party Down (2009-2010) and developing reboots of Cupid (2009) and 90210 (2008-2013) to keep Veronica Mars-and the possibility of the story continuing-on the audience's mind, continuing to talk about the canceled show in interviews, essentially no matter what the topic of the conversation ostensibly was. ${ }^{22}$

To some degree, his efforts panned out. In 2009, Thomas got the opportunity to pitch his idea for a follow-up film to Warner Brothers. ${ }^{23}$ But the studio passed, not believing there was 
an audience. Thomas, it seems, took this setback as a new challenge: Now he just had to prove the audience for his film did, in fact, exist. He and the show's star, Kristen Bell, worked together to keep the possibility of a Veronica movie seem alive during a variety of their press appearances, with Bell famously telling reporters she would gladly finance the movie herself if Warner Brothers would simply relinquish the rights. ${ }^{24}$ In that interview, Bell explained her current goal was to prove to Warner Brothers that an audience did exist. Put in their full context, Bell's remarks in this interview indicate she meant she would be willing to raise the money herself, not pay for it from her own bank account, but the provocative way in which she framed her comments-along with similar statements made by Thomas on several occasions-seemed to make it clear they were trying to galvanize the fan base into action by vilifying Warner Brothers as a tyrannical corporation exerting unnecessary control over a minor piece of intellectual property. On social media, Bell and Thomas worked with their fans to get \#VeronicaMarsMovie trending on Twitter on a number of occasions and encouraged fans to join a Facebook group pledging to see the Veronica Mars movie if it was ever made. Warner Brothers eventually set up an e-mail account, VeronicaMarsMovie@ WarnerBros.com, as an official place to gather fan interest, so Bell and Thomas encouraged fans to write in to the studio directly. ${ }^{25}$ But the roughly twenty thousand messages the studio reported receiving were far from enough to convince them this was a movie worth making.

During this ongoing struggle to prove there was an audience, the practice of crowdfunding, or financing a venture using small donations from many contributors, rapidly gained traction in the world of independent media production, starting with homespun PayPal-based donation pages and institutionalizing with the arrival of a number of platforms dedicated to the practice, most notably Kickstarter and Indiegogo. ${ }^{26}$ In independent production, crowdfunding quickly came to serve as a tool for gaining publicity and tangibly demonstrating the existence of an audience as well as a funding mechanism. ${ }^{27}$ In short, it was just the solution Veronica Mars needed to finally get off the ground. Not only would it provide the production funding the studio was so reluctant to contribute, it would also create a list of people who wanted to see this movie badly enough to finance it themselves. After a year of negotiations with studio, Thomas launched a Kickstarter campaign to raise two million dollars for a Veronica Mars film. The campaign reached its goal in ten hours, ultimately raising 5.7 million in contributions from 91,585 fans. In an interview with Wired, Thomas explained that for Warner Brothers, which does not typically make movies on such a small budget, the campaign was "a way to judge if there was enough interest in a movie this size" as much as a funding tactic. ${ }^{28}$ With the audience established, the studio kicked in well over a million dollars in additional funding to complete production and promote the film.

The alliance Rob Thomas built with fans to make the follow-up movie was enabled by the ways in which his authorial paratext framed the reception of Veronica Mars. By the time the Veronica Mars movie Kickstarter campaign launched in March 2013, the hypothetical "Veronica Mars movie" had been discussed so often that it had become a long-running joke in television journalism. But joke or not, the narrative pitting Thomas against Warner Brothers in a battle to revive this beloved piece of intellectual property had never been far from fans' minds. As fans wanted to see the story continue as well, and had spearheaded their own campaigns to keep it going alongside those initiated by Thomas, ${ }^{29}$ both were united in a mission to protect the story they loved from executives who only cared about turning a profit. In addition, this image of Thomas as a showrunner-of-the-people gained authenticity 
because it pre-dated the cancellation of Veronica Mars. For instance, his primary residence was in Austin, Texas, not Los Angeles.

But perhaps the most significant part of this brand image was the way that Thomas used online social connections with the fans from the beginning. Veronica Mars originally aired before the platform ecosystem of today's social media fully developed, but when the show was on the air, Thomas used earlier versions of social web infrastructure to give production scoop to the recappers at Television Without Pity, often before the mainstream entertainment press, and posted news about his efforts to keep the network from canceling the show on the website's message boards, which were a major hub of the Veronica Mars fandom. ${ }^{30}$ After the show's cancellation, as maintaining a social media presence and using it to cultivate fandom became a more expected part of a showrunner's duties, Thomas changed his tactics with the times, communicating with fans via Twitter and Facebook Groups during his efforts to keep the conversation going. During the Kickstarter campaign itself, Thomas and other production representatives made a point to reciprocate conversation with supporters as much as possible, both within the confines of the Kickstarter platform and all across the social media ecosystem. ${ }^{31}$

Because Thomas had positioned himself as closely aligned with fans and separate from the network(s) and studio since long before Veronica Mars had even been canceled, the ways in which his authorial paratext framed fan understandings of the show made it the perfect project for a studio experiment with the previously indie-dominated crowdfunding model. Other contemporaneous Kickstarter campaigns with big-name industry sponsors, such as the one started by Zach Braff, were roundly criticized at the time, with many critics suggesting they were neither necessary nor ethical. ${ }^{32}$ But while the Veronica Mars movie campaign has also received some critique in both scholarly and journalistic circles, ${ }^{33}$ the dominant discourse suggests it is generally perceived differently from other celebrity crowdfunding attempts. Media coverage of the campaign largely attributed this to the fact that the Kickstarter campaign was preceded by a six-year-long narrative establishing that Thomas and Bell wanted to make this movie, but Warner Brothers would not let them. As Meghan Lewit wrote in The Atlantic,

Despite the fact that the people who stand to benefit financially from the Veronica Mars film are not exactly cash-poor, there [is] an element of populism in the idea of wresting control away from a recalcitrant studio and putting it back in the hands of the show's creator. ${ }^{34}$

Thomas's longstanding alignment with the fans and against the studio gave the campaign an authentic flavor and made this fan/creator alliance seem like a natural way for the show to make a comeback.

\section{The Gas Leak Year: Dan Harmon's Community Comeback}

While Veronica Mars presents a straightforward example of a creator allying with fans to contest a studio's production decision, the case of Dan Harmon and Community presents 
something significantly more complex. To be fully successful, "a television auteur must be seen at once as an effective boss and an inspired genius." ${ }^{35}$ While Harmon has been lauded as a singular creative visionary, he is perhaps even more well-known for being an exceptionally bad manager. His poor budgeting, failure to delegate, borderline-and-not-so-borderline unprofessional social media behavior, and an ugly feud with Community cast member Chevy Chase were all highly public knowledge during the first few years of Community's run. Furthermore, during the wave of sexual harassment and assault revelations that rocked Hollywood in 2017 and 2018, it came to light that Harmon had perpetrated sexual harassment and retaliatory behavior in the Community writers' room during the years of the show's production. In 2012, after three seasons of Harmon's antics, he was fired from his own show, replaced by veteran writer-producer team Moses Port and David Guarascio. A year later, he was back, despite the fact that-evidenced by the scathing comments he made about his once and future bosses on his podcast days after being rehired ${ }^{36}$ - there was nothing to suggest his behavior had improved.

Although there were certainly some fans who directly lobbied Sony and NBC for Harmon's reinstatement, it was definitely not direct fan campaigning that got Harmon his job back. At the time, the primary official story circulating through trade press pointed to insistence from the show's cast, led by star Joel McHale, as a chief motivator behind both Sony's decision to rehire Harmon and NBC's acceptance of it. ${ }^{37}$ Yet though no industry journalist seemed to have an explicit quote on the record, articles reporting on the rehiring suggested a bigger picture in which Sony executives had realized Community simply was no longer Community without the authorial paratext of Dan Harmon framing it. In the face of slipping ratings, dwindling critical praise, and an angry fan base, "Sony execs realized the show had faltered without Harmon"38 and knew they needed him back if they were going to keep their audience. Behind the scenes, Harmon's creative vision had been "deemed essential for inspiring and mobilizing talent and fan labor ... essential to the network's brand image." 39 Without the authorial paratext of Dan Harmon shaping its reception, Community could not survive.

Although Harmon behaved problematically toward both the rest of his show's production staff and the executives he answers to, he always engaged more productively with the fans of his show. Those close to him explain this behavior by saying, "the only boss Dan respects is the audience." ${ }^{\prime 4}$ Harmon's multiplatform mastery of the digital ecosystem surrounding him and his show played a significant role in building and maintaining his relationship with this boss. In addition to the Twitter sharing and conversation that was by this point fairly commonplace among showrunners, he was active on Reddit, maintained a popular and revealing Tumblr blog, "Dan Harmon Poops," engaged with the YouTube culture that sprung up around the show by recreating a popular fan video in the episode Paradigms of Human Memory, ${ }^{41}$ and ran an enormously popular podcast, Harmontown (2012-Present), with free live tapings that were highly popular events for Community fans in Los Angeles. As the scatological title of his Tumblr suggests, Harmon paints a revealing, raw, and not-entirely-pretty portrait of himself in his social media interactions with fans. This performance of dysfunction only bolsters Harmon's authorial paratext, deeply associating him with the trope of the singular-but-troubled genius. Couched in this complex multiplatform performance of authorship, the Community fandom was often just as much a fandom of Harmon as it was of the television text itself. 
When Harmon was fired, his replacements were under scrutiny long before anyone had seen an episode of their version of Community-the discourse around the show was simply too invested in the framing narrative of Harmon's unique sensibility and singular talent. Headlines or thinkpieces inspired by his firing asked "What's Community without Dan Harmon?" 42 and proclaimed "Suits Axe Auteur, and Fans Lose." 43 While Sony and NBC likely hoped the narrative emerging from their decision would coalesce around the idea that the new, responsible showrunners would shepherd the show for far more future seasons than the irresponsible Harmon could be expected to, ${ }^{44}$ it was clear everyone had decided the new Community was a shadow of its former self a full nine months before the first episode of the season aired. Port and Guarascio were probably facing a battle of perception they could not win, no matter how excellent the new season might turn out to be. But regardless of whether these new showrunners captured the tone of the series within the scripts they wrote and supervised, they clearly failed to reproduce Harmon's relationship with the fan base. Port and Guarascio alienated the fans, not just by producing a product perceived as inferior but by dramatically reducing their level of interactivity with the fans and even mocking them in interviews. ${ }^{45}$

In this situation, Harmon's authorial paratext, which suggested he was the only creative voice who could do Community justice, probably did not need to be reinforced. But while his replacements were alienating Community's dedicated fan base, Harmon was traveling around the country, connecting with them in person as he recorded his podcast. He had started the Harmontown podcast as an outlet for the many stresses he experienced as a showrunner and used it to connect with a live audience of fans at Nerdist Comics in Los Angeles. Although the podcast was not explicitly focused on Community, the two shows largely shared a fan base. And like many of Harmon's other engagements with fans, Harmontown often got him in trouble with his bosses at the studio-most notably during an incident shortly before his firing when he played angry voicemails from cast member Chevy Chase for the audience at a taping. This action made the feud between the two public, further demonstrating his mismanagement of the talent he employed. Unlike Community, Harmontown unequivocally belonged to Dan Harmon. So after he was fired, he decided to take the podcast on a national tour.

In director Neil Berkley's documentary chronicling the podcast tour-also called Harmontown (2014) - the paratext of Dan Harmon's singular, troubled genius is broken down and reconstructed in fascinating ways. Throughout the documentary, Harmon is unable to articulate anything about why he is doing this or what it means. But everyone around him-from his girlfriend to random fans he meets in various college towns-is constantly imbuing the podcast, the tour, and Community with deep significance, showcasing the ways in which the television author is constructed by the audience. In one particularly memorable moment, a University of Texas film student asks Harmon,

So to me, all of your work is about connecting people, and turning a passive audience into an active one ... was this always in your head to, like, get fans out of their chairs and producing content?

Harmon seems baffled by the question, coming across as an absolute cipher, empty of the meaning this fan is projecting onto him. In these moments, it frequently feels as though Harmon the genius author is an invention of the fans with little relation to the self-loathing alcoholic on the screen. Though self-aware in many other ways, Harmon appears utterly flummoxed by his own cultural significance. 
For Harmon, it seems clear this road trip emerged as a coping mechanism in which he was trying to replace the sitcom he had lost with a comedy show he could control. Although he is unsure of his value to them, by connecting directly with the fans, he seems able to regain some external validation he lost when he was fired by Sony. He hopes to entertain his audiences, but mainly so that they can reassure him he is entertaining. At every stop on the tour, Harmon aggressively performs the role of the canceled author, making his depression and self-loathing visible to the point where he blacks out from drinking on stage during one performance. Even as he heckles the audience for responding positively to him, he clings to the validation their fandom provides. At the end of the tour, summing up the experience, he focuses on what he has gained psychologically from the experience, noting that it is important for someone like him to know he has the ability to influence people. Perhaps most tellingly, he explains, "I thought this [tour] would be about me getting better and better at doing a show, but it's ended up being about me realizing I don't need to have one." Significantly, Harmon has explicitly stated that he would never have accepted the job when it was reoffered to him if he had not gone on the Harmontown tour, noting that it offered a different perspective on the connections he had built with his fans than just interacting with them on social media had:

If my only interaction with the audience was through the show itself, through Reddit, through Tumblr, through Twitter, and then, by proxy, through these nobles who hire and fire you, then I don't think I would have had it in me to go back to the fifth season ... Instead, I hugged some very warm, trembling bodies. I don't know if they were relying on me to make Community or not. It could have been strangers that had never seen the show, but I think a lot of human contact helped me make a different decision, when I got reoffered the job, than I would have made. ${ }^{46}$

Harmon clearly did not start the Harmontown tour to show his former bosses at Sony that they had made a mistake. His motivations were visibly, even selfishly, personal. But regardless of Harmon's intentions, his actions clearly reproduced the community that emerged around his sitcom. Community is a show about a study group at a fictional community college, but it uses that setting as the backdrop for a frenetic parody of/homage to pop culture driven by the theme of outsiders banding together to form a chosen family. Harmon did not own the rights to Troy and Abed, or to Greendale Community College, but his podcast tour drew on the same themes and the pop culture that enlivened Community. The same people who fervently coalesced around the television show recreated their fan community around Harmon's tour at the same moment that replacing him had caused the fan community surrounding the television show to fragment.

Sony executives may or may not have been paying attention to the community Harmon was building around his podcast during his absence from Community, but they certainly learned that his authorial paratext was an essential part of the reason Community had been surrounded by an intense, invested group of fans. Without Harmon, those fans were disengaged. Because Community is more valuable to Sony if more episodes are produced, they needed to keep the audience to justify continued production. This meant rehiring Harmon to recover the branding provided by his authorship. Although Harmon's motivations for going on the Harmontown tour were primarily personal, his interactions with fans during the tour made it clear-if not to Sony, then certainly to Harmon himself-that he 
was a figure who inspired the audience to become active. In an era where large coalition audiences are a thing of the past, and narrower, deeply engaged active audiences have increased value, the ability to inspire fan community makes Harmon exceptionally valuable to corporate television producers, forcing them to overlook other issues with his management.

\section{Post-Network Patronage: The Fan/Creator Alliance}

Although the specifics of their cases are quite different, both Rob Thomas and Dan Harmon in some way used an alliance with their fans to regain control of intellectual property that they had lost as a result of television's copyright structures. Thomas straightforwardly needed to prove that there was an audience for his movie. While Harmon did not necessarily set out to prove something to his ex-bosses at Sony, the Harmontown tour demonstrated his significance as a figure that brought and held together the fan community a low-rated cult series like Community desperately needs to survive. Both the individual authorial paratexts of Harmon the troubled genius and Thomas the antiestablishment everyman are infused with a sense that these creators are far more aligned with the fans of their shows than with the corporate entities that produce and distribute them. This highlights the fact that in the structures of television production, creators exist in a somewhat liminal position. While some, for example Aaron Sorkin, work to position themselves as powerful industrial elites set apart from their fans, more savvy showrunners can be observed actively working the margins between their industry status and their fans. With social media making these margins more explicitly visible, today showrunners have ample opportunity to use their connection with fans to shift the balance of power in their favor during moments of contested industry decision making.

Fan studies discourses about the relationships between fans and production have often lumped creators and showrunners in with a more general concept of "producers," "industry," and corporate ideology. ${ }^{47}$ Simultaneously, they often figure fandom as resistant to these corporate ideologies. But what about situations in which showrunners and other creators are resistant to corporate ideology? The cases of Dan Harmon and Rob Thomas demonstrate the need for a more complex understanding of the ways in which fans relate to different parties in the production process-as well as the ways in which the different parties in the production process relate to them. Although they are sponsored and supported by the corporate entities of the studio and network, the interests of showrunners are not inherently aligned with the interests of those corporate entities, and they foster different types of engagement with their audiences as a result of those differing interests. When disputes arise between studios and showrunners, audience respect is the most significant currency they have at their disposal. While networks have the legal upper hand, showrunners gain their leverage from their reputations. Although industrial narratives-particularly paratexts touching on the issue of authorship-may suggest a reputation that would be particularly beneficial to a showrunner, in truth, the desired authorial status can only truly be conferred upon an individual showrunner by audience validation. 
In this way, the relationships showrunners develop with their fans serve as a form of symbolic patronage. Historically, the ability to gain a patron gave artists greater credibility with the public and in the market. ${ }^{48}$ Today, positive relationships with fans enabled by television's social media ecosystem boost the artistic/authorial credibility of showrunners. This credibility carries a significant value for an individual showrunner, as it fashions his or her name into a paratext that comes with connotations of quality and value. The authorial paratext, in turn, serves a major commercial function, acting as branding for studios and networks. This makes creators with more authorial capital more valuable in the industry's labor market, and they can leverage this value to earn more creative autonomy. Although the symbolic patronage of fans is not always in and of itself enough to keep a low-rated show on the air, it certainly can buttress the commercial viability of a showrunner's work, giving them far more ability to influence corporate decision making. Conversely, when the studio or network is seen as interfering with the showrunner's vision, they lose credibility in the eyes of the audience. ${ }^{49}$ When a dispute-as large as cancellation or firing, or as small as disliked script notesarises between a showrunner and the studio or network, the authority granted by the symbolic patronage of fans serves as leverage that empowers the showrunner to argue with their corporate bosses' judgments.

This deeper understanding of how the liminal status of television creators enables them to leverage their relationships with the audience in situations where their interests are not aligned with the studio's is a good first step toward expanding and deepening our understanding of how fans and production relate to each other in the digital media economy. However, fans, creators, and executives are only a few of the many parties involved in these relationships, and I have neglected many others. As both Kristen Bell and Joel McHale's visible roles in these case studies demonstrate, the support of stars plays a substantial role in shaping audience perceptions of authorship. And many fans have relationships with other writers and writer-producers who work under the showrunner. This may complicate their perceptions of authorship, forcing various industrial parties to negotiate the presentation of collective creativity alongside that of the singular authorial paratext. Future work must take up the task of mapping the roles these figures-and many others-play in the complex power dynamics of audience/industry relations.

The digital era has been filled with both utopian rhetoric about the increased power of audiences and caution that participatory culture may be more illusory than it appears. While, as with most things, the truth is somewhere in the middle, the symbolic patronage that audience support provides for television showrunners provides one example of a way audiences have greater control over the industry than in the past. In the past television has always failed or succeeded on the basis of attracting an audience, but its legitimation as an artistic form-a legitimation in many ways enabled by the discursive construction of the showrunner figure-has allowed some programs to continue with lower ratings than they might have in the past because of the greater cultural capital those programs now possess. The ability to bestow authorial capital upon television showrunners thus represents one significant way in which fans can influence industry decision making in a clear but indirect fashion.

${ }^{1}$ Annemarie Navar-Gill is a PhD candidate in Communication Studies at University of Michigan. She received her bachelor's degree in Writing for Screen and Television 
from the University of Southern California and worked in the television industry for six years, most notably writing for the CW series Gossip Girl. Her research focuses on labor and technology in media and information industries.

${ }^{2}$ Miranda Banks, The Writers: A History of the American Screenwriters and Their Guild (New Brunswick, NJ: Rutgers University Press, 2016); Catherine Fisk, Writing for Hire: Unions, Hollywood, and Madison Avenue (Cambridge, MA: Harvard University Press, 2016).

${ }^{3}$ Banks, The Writers; Alisa Perren and Thomas Schatz, "Theorizing Television's Writer-Producer: Re-Viewing the Producer's Medium," Television \& New Media 16 $(1,2014)$ : 86-93.

${ }^{4}$ Michael Z. Newman and Elana Levine, Legitimating Television: Media Convergence and Cultural Status (NY: Routledge, 2012).

${ }^{5}$ Derek Kompare, "More Moments of Television: Online Cult Television Authorship." in Flow TV: Television in the Age of Media Convergence," ed. M. Kackman, M. Binfield, A. T. Payne, A. Perlman, and B. Sebok (NY: Routledge, 2011), 95-113.

${ }^{6}$ Jason Mittell, Complex TV: The Poetics of Contemporary Television Storytelling (NY: New York University Press, 2015); Jennifer Holt and Kevin Sanson, eds., Connected Viewing: Selling, Streaming, and Sharing Media in the Digital Age (NY: Routledge, 2013).

${ }^{7}$ Fisk, Writing for Hire.

${ }^{8}$ Banks, The Writers, 234.

${ }^{9}$ Fisk, Writing for Hire.

${ }^{10}$ Ibid.

${ }^{11}$ Banks, The Writers; Horace Newcomb and Robert S. Alley, The Producer's Medium: Conversations with Creators of American TV (NY: Oxford University Press, 1985).

${ }^{12}$ Fisk, Writing for Hire, 14.

${ }^{13}$ Mittell, Complex TV.

14 Jonathan Gray, Show Sold Separately: Promos, Spoilers, and Other Media Paratexts (NY: New York University Press, 2010), 25.

${ }^{15}$ Fisk, Writing for Hire, 21.

${ }^{16}$ Derek Johnson, "Fan-Tagonism: Factions, Institutions, and Conservative Hegemonies of Fandom," in Fandom: Identities and Communities in a Mediated World, ed. Jonathan Gray, Cornel Sandvoss, and C. Lee Harrington (NY: New York University Press, 2007), 285-300.

${ }^{17}$ Denise Bielby, C. Lee Harrington, and William T. Bielby, "Whose Stories Are They? Fans' Engagements with Soap Opera Narratives in Three Sites of Fan Activity," Journal of Broadcasting E Electronic Media 43 (1, 1999): 35-51; Sharon Marie Ross, Beyond the Box: Television and the Internet (Oxford: Blackwell Publishing, 2008).

18 Tanya R. Cochran, "Neptune (Non-)Consensual: The Risky Business of Television Fandom, Falling in Love, and Playing the Victim," in Investigating Veronica Mars: Essays on the Teen Detective Series, ed. by Rhonda Wilcox and Sue Turnbull (Jefferson, NC: McFarland, 2011), 167-87; Henry Jenkins, "The Guiding Spirit and the Powers That Be: A Response to Suzanne Scott," in The Participatory Cultures Handbook, ed. Aaron Delwiche and Jennifer Jacobs Henderson (NY: Routledge, 2013), 43-52; Annemarie Navar-Gill, "Fandom as Symbolic Patronage: Expanding 
Understanding of Fan Relationships with Industry Through the Veronica Mars Kickstarter Campaign," Popular Communication 16 (3, 2018): 211-24.

${ }^{19}$ Kristen M. Barton, "Chuck Versus the Advertiser: How Fan Activism and Footlong Sandwiches Saved a Television Series," in Fan CULTure: Essays on Participatory Fandom in the $21^{\text {st }}$ Century, ed. Jonathan Malcolm Lampley and Kristin M. Barton (Jefferson, NC: McFarland, 2013), 159-72.

${ }^{20}$ Holt and Sanson, Connected Viewing.

${ }^{21}$ Elizabeth Evans, "Tweeting on the BBC," in Making Media Work: Cultures of Management in the Entertainment Industries, ed. Derek Johnson, Derek Kompare, and Avi Santo (NY: New York University Press, 2014), 235-54; Annemarie Navar-Gill, "From Strategic Retweets to Group Hangs: Writers' Room Twitter Accounts and the Productive Ecosystem of TV Social Media Fans," Television \& New Media 19 (5, 2018): 415-30.

${ }^{22}$ Michael Ausiello, "Exclusive: 'Veronica Mars' Creator Insists Movie Is 'Not Dead'." EW.com, April 7, 2010, http://insidetv.ew.com/2010/04/07/veronica-marsmovie-is-not-dead/ (accessed December 18, 2014); Kristen Dos Santos and Megan Masters, "Rob Thomas Speaks Out on Party Down Cancellation-Is the Veronica Mars Movie Next?" E! Online, June 30, 2010, http://www.eonline.com/news/188368/ rob-thomas-speaks-out-on-party-down-cancellation-is-the-veronica-marsmovie-next (accessed December 21, 2014).

${ }^{23}$ Michael Ausiello, "Exclusive 'Veronica Mars' Movie Update: 'It's Close'," EW.com, February 9, 2009, http://insidetv.ew.com/2009/02/09/exclusive-veron/ (accessed December 18, 2014).

${ }^{24}$ Lesley Goldberg, "Kristen Bell Would Finance 'Veronica Mars' Pic," The Hollywood Reporter, September 23, 2010, http://www.hollywoodreporter.com/news / kristen-bell-would-finance-veronica-28240 (accessed December 11, 2014).

${ }^{25}$ Chris Harnick, "EXCLUSIVE: Rob Thomas Calls WB's 'Veronica Mars' Movie Email Address a 'Glimmer of Hope'," The Huffington Post, http://www.aoltv. com/2010/11/10/veronica-mars-movie-rob-thomas / (accessed July 11, 2014).

${ }^{26}$ Aymar Jean Christian, Open TV: Innovation beyond Hollywood and the Rise of Web Television (NY: NYU Press, 2018).

${ }^{27}$ Sara Bannerman, "Crowdfunding Culture," Wi: The Journal of Mobile Media 7 (1, 2013), http://wi.mobilities.ca/crowdfunding-culture/; Inge Ejbye Sørensen, "Crowdsourcing and Outsourcing: The Impact of Online Funding and Distribution on the Documentary Film Industry in the UK," Media, Culture E Society 34 (6, 2012): 726-43.

${ }^{28}$ Laura Hudson, "Rob Thomas on His \$5M Veronica Mars Kickstarter and the Future of Fan-Funded Film," WIRED, April 12, 2013, http://www.wired.com/2013/04/ rob-thomas-interview-veronica-mars-kickstarter / (accessed December 19, 2014).

${ }^{29}$ Cochran, "Neptune (Non-)Consensual."

${ }^{30}$ Rob Thomas, "A Message from Rob Thomas-Veronica Mars General Gabbery," TWoP Forums," January 29, 2005, https://web.archive.org/web/20140331112346/ http://forums.televisionwithoutpity.com/topic/3122604-a-message-from-robthomas/.

${ }^{31}$ Navar-Gill, "Fandom as Symbolic Patronage." 
${ }^{32}$ Ben Child, "Zach Braff Kickstarter Controversy Deepens after Financier Bolsters Budget," The Guardian, May 16, 2013, http://www.theguardian.com/film/2013/ may/16/zach-braff-kickstarter-controversy-deepens (accessed December 18, 2014).

${ }^{33}$ Sam Adams, "Did Veronica Mars Ruin Kickstarter?" Slate, March 15, 2013, http:// www.slate.com/blogs/browbeat/2013/03/15/veronica_mars_movie_project_ kickstarter_campaign_did_it_ruin_crowd_funding.html (accessed December 18, 2014); Bertha Chin, Bethan Jones, Myles McNutt, and Luke Pebler, "Veronica Mars Kickstarter and Crowd Funding," Transformative Works and Cultures 15 (2013).

${ }^{34}$ Meghan Lewit, "Why Hate Zach Braff's Kickstarter Campaign but Not Veronica Mars's?" The Atlantic, April 26, 2013, http://www.theatlantic.com/entertainment/archive/2013/04/why-hate-zach-braffs-kickstarter-campaign-but-notveronica-marss/275338/ (accessed December 11, 2014).

${ }^{35}$ Newman and Levine, Legitimating Television.

${ }^{36}$ Jethro Nededog, "Rehired 'Community' Boss Dan Harmon Blasts Sony TV Ahead of His Return," The Wrap, June 17, 2013, http://www.thewrap.com/tv/article/ rehired-community-boss-dan-harmon-bashes-sony-tv-ahead-his-return-97871/ (accessed December 21, 2014).

${ }^{37}$ Josef Adalian, "Dan Harmon Got Rehired for Community for the Same Reason He Got Fired," Vulture, June 19, 2013, http://www.vulture.com/2013/06/why-sonybrought-dan-harmon-back-to-community.html (accessed December 19, 2014).

${ }^{38}$ Lacey Rose, "'Community's' Dan Harmon Reveals the Wild Story Behind His Firing and Rehiring," The Hollywood Reporter, July 17, 2013, http://www.hollywoodreporter.com/news/communitys-dan-harmon-reveals-wild-586084 (accessed December 19, 2014).

${ }^{39}$ Derek Johnson, Derek Kompare, and Avi Santo, eds. Making Media Work: Cultures of Management in the Entertainment Industries (NY: New York University Press, 2014), 21.

${ }^{40}$ Neil Berkeley, Harmontown, Documentary, 2014.

${ }^{41}$ Rekha Sharma, "Community Clip Show: Examining the Recursive Collaboration between Producers and Viewers of a Postmodern Sitcom," The Journal of Fandom Studies 1 (2, 2013): 183-99.

${ }^{42}$ Willa Paskin, "What's 'Community' without Dan Harmon?" Salon, May 21, 2012, http://www.salon.com/2012/05/21/whats_community_without_dan_ harmon/ (accessed December 22, 2014).

${ }^{43}$ James Poniewozik, "Community without Dan Harmon? Suits Axe Auteur, and Fans Lose," Time, May 19, 2012, http://entertainment.time.com/2012/05/19/communitywithout-dan-harmon-suits-axe-auteur-and-fans-lose/ (accessed December 22, 2014).

${ }^{44}$ Adalian, "Dan Harmon Got Rehired."

${ }^{45}$ Sharma, "Community Clip Show."

${ }^{46}$ Jesse David Fox, "Dan Harmon on Harmontown, the Documentary about the Tour That Saved Community," Vulture, October 10, 2014, http://www .vulture.com/2014/10/dan-harmon-on-community-harmontown.html (accessed December 21, 2014). 
${ }^{47}$ For example Henry Jenkins, Convergence Culture: Where Old and New Media Collide (NY: New York University Press, 2006).

${ }^{48}$ Judith H. Balfe, Paying the Piper: Causes and Consequences of Art Patronage (Urbana: University of Illinois Press, 1993).

${ }^{49}$ Cochran, "Neptune (Non-)Consensual."

\section{Bibliography}

Balfe, Judith H. Paying the Piper: Causes and Consequences of Art Patronage. Urbana: University of Illinois Press, 1993.

Banks, Miranda J. The Writers: A History of American Screenwriters and their Guild. New Brunswick, NJ: Rutgers University Press, 2015. https://muse.jhu.edu/book/36776.

Bannerman, Sara. "Crowdfunding Culture." Wi: Journal of Mobile Media 7, no. 1 (2013). http:// wi.mobilities.ca/crowdfunding-culture/

Barton, Kristin M. "Chuck Versus the Advertiser: How Fan Activism and Footlong Sandwiches Saved a Television Series." In Fan CULTure: Essays on Participatory Fandom in the 21st Century, edited by Jonathan Malcolm Lampley and Kristin M. Barton, 159-72. Jefferson, NC: McFarland, 2013.

Bielby, Denise D., C. Lee Harrington, and William T. Bielby. "Whose Stories Are They? Fans' Engagement with Soap Opera Narratives in Three Sites of Fan Activity." Journal of Broadcasting E Electronic Media 43, no. 1 (1999): 35-51.

Cantor, Muriel G. The Hollywood TV Producer: His Work and His Audience. Piscataway, NJ: Transaction Publishers, 1979.

Chin, Bertha, Bethan Jones, Myles McNutt, and Luke Pebler. "Veronica Mars Kickstarter and Crowd Funding." Transformative Works and Cultures 15 (May 7, 2013).

Christian, Aymar Jean. Open TV: Innovation beyond Hollywood and the Rise of Web Television. New York: NYU Press, 2018.

Cochran, Tanya R. "Neptune (Non-)Consensual: The Risky Business of Television Fandom, Falling in Love, and Playing the Victim." In Investigating Veronica Mars: Essays on the Teen Detective Series, edited by Rhonda Wilcox and Sue Turnbull, 167-87. Jefferson, NC: McFarland, 2011.

Evans, Elizabeth. "Tweeting on the BBC." In Making Media Work: Cultures of Management in the Entertainment Industries, edited by Derek Johnson, Derek Kompare, and Avi Santo, 235-54. New York: New York University Press, 2014.

Fisk, Catherine L. Writing for Hire: Unions, Hollywood, and Madison Avenue. Cambridge, MA: Harvard University Press, 2016, x, 308.

Foucault, Michel. "What Is an Author?" In The Foucault Reader, edited by Paul Rabinow, 101-20. New York: Pantheon, 1979. 
Gray, Jonathan. Show Sold Separately: Promos, Spoilers, and Other Media Paratexts. New York: New York University Press, 2010.

Holt, Jennifer, and Kevin Sanson, eds. Connected Viewing: Selling, Streaming, E Sharing Media in the Digital Age. 1 ed. New York: Routledge, 2013.

Jenkins, Henry. Convergence Culture: Where Old and New Media Collide. New York: New York University Press, 2006.

Jenkins, Henry. "The Guiding Spirit and the Powers That Be: A Response to Suzanne Scott." In The Participatory Cultures Handbook, edited by Aaron Delwiche and Jennifer Jacobs Henderson, 43-52, New York: Routledge, 2012.Johnson, Derek. "Fan-Tagonism: Factions, Institutions, and Conservative Hegemonies of Fandom." In Fandom: Identities and Communities in a Mediated World, edited by Jonathan Gray, Cornel. Sandvoss, and C. Lee Harrington, 285-300. New York: New York University Press, 2007.

Johnson, Derek, Derek Kompare, and Avi Santo, eds. Making Media Work: Cultures of Management in the Entertainment Industries. New York: New York University Press, $2014,3$.

Kompare, Derek. "More Moments of Television: Online Cult Television Authorship." In Flow TV: Television in the Age of Media Convergence, edited by M. Kackman, M. Binfield, A. T. Payne, A. Perlman, and B. Sebok, 95-113. New York: Routledge, 2011.

Mittell, Jason. Complex TV: The Poetics of Contemporary Television Storytelling. New York: New York University Press, 2015.

Navar-Gill, Annemarie. "Fandom as Symbolic Patronage: Expanding Understanding of Fan Relationships with Industry through the Veronica Mars Kickstarter Campaign." Popular Communication 16, no. 3 (2018): 211-24. doi:10.1080/15405702.2018.1453069.

Navar-Gill, Annemarie. "From Strategic Retweets to Group Hangs: Writers' Room Twitter Accounts and the Productive Ecosystem of TV Social Media Fans." Television \& New Media 19, no. 5 (2018): 415-30. doi:10.1177/1527476417728376.

Newcomb, Horace, and Robert S. Alley. The Producer's Medium: Conversations with Creators of American TV. New York: Oxford University Press, 1983.

Newman, Michael Z., and Elana Levine. Legitimating Television: Media Convergence and Cultural Status. New York: Routledge, 2012.

Perren, Alisa, and Thomas Schatz. "Theorizing Television's Writer-Producer Re-Viewing the Producer's Medium." Television E New Media 16, no. 1 (2014): 86-93.

Ross, Sharon Marie. Beyond the Box: Television and the Internet. Oxford: Blackwell Publishing, 2008.

Sharma, Rekha. "Community Clip Show: Examining the Recursive Collaboration between Producers and Viewers of a Postmodern Sitcom." The Journal of Fandom Studies 1, no. 2 (2013): 183-99.

Sørensen, Inge Ejbye. "Crowdsourcing and Outsourcing: The Impact of Online Funding and Distribution on the Documentary Film Industry in the UK." Media, Culture \& Society 34, no. 6 (September 1, 2012): 726-43. 